\section{TV: linguagem, produção culłural e o resgate da oralidade}

\section{Luíza Carravetta}

Pus-Drutora em Técvislo pela UCLA - USA

Profeseora do Fongraduachio em Comunicacho - PUCRS

\section{Todo mundo vê tovê}

A televisáo $\hat{X}$ COMTUtov 40 anos no Brasil. Esse fenômeno, entretanto, parece ser desconhecido da escola. Criou-se até um mito de que a tevê atrapalha o desenvolvimento das crianças.

Na verdade, é incontestável o fato de que todo mundo vê tevê. Crianças, pais, professores, todos vêem tevê. Pesquisas apontam que a criança, em idade escolar, permanece em média cinco horas diante da televisaa. Computadas as horas $\mathrm{em}$ que os alunos permanecem assistindoàtevê, concluise que mais tempoc ecupado com o aparelho do que com as horas de permanència das criançasnaescolaco respectivoenvolvimento com as tarefas escolares.

A escola năo pode culpar a tevê por falhas que sào suas. O problema năo é a tevê, é a própria escola que parou no tempo, ancorando-se no século passado. Ela alienase, não se ligando à cultura dos alunos nem à dos professores.

Durante muito tempo, a cultura predominante da escola foi a cultura escrita. Em decorrência disso, como, principal metodologia, a escola vem utilizandoo textoescrito ou o texto didático. Acontece que estamos no séculovinte, numaera pós-Gutemberg, noutro momento histórico, ou seja, na era da eletrônica. E,comoa escola ainda está atrelada à cultura da escrita, ela critica a tevê e lamenta o espaço perdido para ela.

Infelizmente, para a escola, cultura é somente livro, nào havendo espaco para os meios de comunicaçăo de massa: rádio, cinema, jornal e televisło.

A escola náo percebeu que ela precisa convivercomatevê. Desconhecendoosucesso e a existência da tevê, fica mais fácil condenála. Por isso, é preciso trazer a tevê para a 
escola, mormente para a sala de aula, pois ela pode tornar-se uma verdadeira aliada na tarefa de educar.

A televisão pode contribuir para criar um espírito crítico e dar um certo apuro estético para os que assistem a ela. $O$ importante ésaber ver tevê criticamente. Pais e professores precisam mudar sua postura em relaçào ao veículo. É precisoorientar filhos e alunos, conversando, trocando idéias, ajudandoaselecionar os melhores programas para a complementaçăo da educaçăo, oferecida pela familia e pela escola. Diante destes pressupostos o resgate da imaginaço criadora é fundamental.

O ideal seria a escola abrir suas portas para a linguagem da tevê, linguagem da imagem e nào só da escrita, trabalhando com os alunos programas de televisăo como recurso didático.

Outra alternativa seria trabalhar com videoprogramas instrucionais, alertando os alunos para a linguagem da imagem e todas as suas possibilidades de leitura.

\section{Linguagom da fovê}

Comunicação significa, para a Linguística, uma atividade psicofísica de uma interaçào intencional de duas mentes através do uso de signos orais duplamente articulados.

Eem Ferdinand de Saussure (1972) que se origina a teoria do signo linguístico. Para ele, signo é uma entidade psíquica, um ser metafísico, criadodentro da mente pela unilo do significado, ou seja, do conceito e do significante, imagem acústica.

O signo linguistico não une um objetoe uma palavra, mas um conceitoe uma imagem acústica, apresentando uma estreita unidade entre significante esignificado. Osignificante é a imagem da forma fônica, ao passo que o significado é a imagem mental da coisa.

De acordo com a teoria de Saussure (1972), o signo lingúistico está na mente, criase na mente. Sendo assim não é suficiente para o processo de comunicaşão.
Peirce define osigno do seguinte modo: "signo é algo que, sob certo aspecto ou de algum modo, representa alguma coisa para alguém. Dirige-se a alguém, isto é, cria na mente dessa pessoa um signo equivalente ou talvez um signo melhor desenvolvido. Ao signo assim criado, denominamos interpretante do primeiro signo. O signo representa alguma coisa, seu objeto. Coloca-se no lugar desse objeto, năo sob todos os aspectos, mas com referência a um tipo de idéia que tenho por vezes denominado o fundamento do signo". (Peirce, 1971, p.94) .

Observa-se nessa definiçào que signo é uma coisa que substitui outra. A relaşão triádica de Peirce(1971) é assim representada:

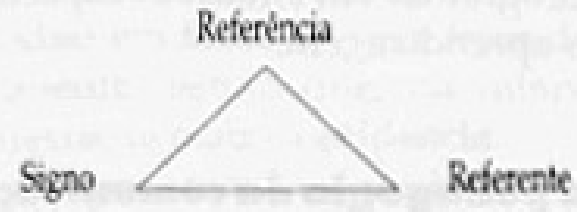

A contribuiçăo de Pierceé fundamental, a fim de que se possa entender linguagem como representaçăo. Partindo da relaçăo de representaçăo do signo com o seu objeto, produz-se na mente interpretadora um outro signo que traduz o significado do primeiro.

Algumas definiçōes importantes complementama teoria de Peirce(1971) que estuda o signo semiológico como alguma coisa que representa alguma coisa que representa algo para alguém.

1) ícone: semelhança ou analogia como referente ( foto, esquema),

2) índice: mantém relaço direta com o referente (chão molhado-chuva),

3) símbolo: relașio com o referente é arbitrária e convencional (linguagem falada ou escrita).

Os recursos de aprendizagem pela tevê baseiam-sena linguagem iconicaou imagética e na imagem sonora, compreendendo os sons inerentes aos próprios objetos das imagens, a linguagem oral ou musical ou a linguagem escrita.

A aprendizagem decorrente do uso da tevê ocorre pelo uso da imagem icônica, da 
qual a imagem sonora é um item, pois as imagens falam ou produzem sons, muitas vezes ambientados pela linguagem musical.

Os recursos da imagem (figura) e do questionamento do real que ela possibilita concretizam e garantem a comunicação entre os agentes pedagógicos, ou seja, entre professor e alunos.

Osigno icônico provoca uma consciência em aberto, uma consciência do "vir a ser", passivel de descobertas, uma consciência que escapa a controles prévios.

A compreensão do signo lingüístico e do signo icônico como recurso de aprendizagem devem fazer parte do referencial teórico do professor que vai usar a televisão e os videoprogramas em situações específicas de ensino-aprendizagem.

\section{Por uma pedagogia da comunicação}

A necessidade de encontrar formas adequadas para buscar o conhecimento constitui-se num grande desafio para a escola. Por isso, o significado do prazer ou desprazer que envolve a relação professor-aluno no seu trabalho com o conteúdo é fundamental para o desenvolvimento do processo ensinoaprendizagem.

Oensino teórico, livresco, enciclopédico, afastado da experimentação, da ação prática, põe em risco toda a criatividade $\mathrm{e}$ inventividade da criança e neste sentido resgata processoscriativos, torna-se de grande importância diante das etapas do desenvolvimento infantil (Lowenfeld, 1977).

A convivencia social no cotidiano da escola, na exigência comunicacional e na compreensão do ponto de vista do outro remetem à importância do jogo, do ludismo, já referenciados por Piaget (1979) na construção das estruturas mentais.

O ludismo favorece o desenvolvimento dos estágios de pensamento, advindo daí a importância de tal atividade para o desenvolvimento mental das crianças.

Piaget preocupa-se com os objetivos da educação, propondo uma escola nova, constituída de métodos ativos, onde a meta prioritária é formar individuos, capazes de criar e não apenas ficar repetindo padrōes já existentes.

Os estudos de Piaste (1973, 1979) referem-se ao desenvolvimento biológico e psicológico paralelamente.

Partindo da conceitualização de reversibilidade, que é a capacidade que um individuo tem para executar uma mesma ação nos sentidos de ida e volta, tendo consciência de se tratar da mesma ação, Piaget divide o desenvolvimento mental da criança em quatro etapas, deacordo com o processo de conquista da reversibilidade.

O primeiro período chama-se sensóriomotor e vai do nascimento até os dezoito meses. Nesse período não há nenhum indício de reversibilidade operatória. $\mathrm{O}$ segundo período, período do pensamento intuitivo, começa aos dois e vai até os sete anos, onde se iniciam operações semi-reversíveis. No terceiro período, de sete a doze anos, período das operações concretas, alcança-se uma reversibilidade na formação das primeiras estruturas operatórias. Finalmente, no quarto período, dos doze anos em diante, período das operações proposicionais, alcança-se uma reversibilidade completa.

A teoria de Piaget ressalta dois fatores fundamentais: a construção do conhecimento, embasada nos estágios de desenvolvimento mental, e a importância do ludismo, na construção de tais estruturas.

Um dos principais tópicos da epistemologia, construída ao longo da obra de Piaget (1973, 1979), diz respeito ao jogo, como instrumento de técnicas pedagógicas e terapêuticas.

Saviani (1984), na sua pedagogia transformadora, propõe uma escola interessada em métodos de ensino eficazes, que estimulem a criatividade e a iniciativa dos alunos, os ritmos de aprendizagem e o desenvolvimento psicológico, sem perder de vista a sistematização lógica do conhecimento, sua ordenação gradação, para a assimilação dos conteúdos cognitivos.

O autor ainda propōe passos metodo- 
lógicos, baseados numa prática social. Partindo de uma práxis e passando por identificação de problemas, instrumentalização, catarse e chegando novamente à práxis, Saviani propõe uma pedagogia em torno dos agentes pedagógicos, ou seja, professores e alunos, na sua dimensão maior de agentes sociais.

Freire (1979) acrescenta aos passos, sugeridos por Saviani (1984), os recursos da imagem e do questionamento que ela possibilita, concretizando e garantindo o processo de comunicação entre os agentes pedagógicos.

Em seu método, Freire apresenta, ao lado da palavra escrita, o ícone, representativo da situação social do aluno, no qual a palavra está assegurando que as representações mentais a serem trabalhadas durante o processo ensino-aprendizagem sejam as mesmas do aluno, garantindo que a "leitura do mundo" precede a leitura da palavra.

A consciência icônica do aluno é mobilizada através de situações de sua experiência de vida. A consciência simbólica, que é lógica, é a meta, pois permite o raciocínio, além da sensação imediata.

O método de Paulo Freire fundamentase no diálogo, partindo da consciência icônica e do questionamento, da indagação e da informação. O método prevê levar o aluno de um ponto a outro.

Paulo Freire chama atençāo para o fato de que "ver" uma imagem representando a situação não é a mesma coisa que ler sobre a situação.

A pedagogia da comunicação deve levar em conta a leitura das imagens icônicas. A palavra dá margem à construção da representação mental do receptor, enquanto que a figura delimita-a em grande parte, visto que circunstancializa a imagem.

Seosigno utilizadona situação de ensino é a palavra, há a possibilidade de que o professor esteja usando determinado recorte da realidade, enquanto o aluno usa outro, pois possuem referenciais diferentes de experiência. A figura traz à tona a consciência icônica, baseada no sentimento e na intuição, construída nas relações com os objetos.

Osigno icônico tem uma analogia como objetivo representado. $\mathrm{O}$ receptor do icone pode conhecê-lo ou reconhecê-lo, uma vez que não há exigência de familiaridade do receptor com a realidade a que ele se refere. Isso permite ver o icone como um signo, capaz de propor o novo, como um signo que revela. Por isso, o signo icônico provoca uma consciência em aberto, passivel de descobertas, propondo uma nova metodologia, baseada numa pedagogia para a comunicação.

\section{O jogo e a oralidade}

A atividade lúdica acompanha o individuo em todas as suas fases de desenvolvimento, sendo que, na infância, sua manifestação mais se evidencia.

Ojogo, mesmo não sendo uma atividade unicamente infantil, tem sua iniciação na infância, onde as crianças estão na fase de explorar o mundo através de todas as suas manifestações, procurando adaptar-se a ele, explorando seus sentimentos e suas emoções.

$\mathrm{O}$ jogo constitui-se numa atividade espontânea, individual ou social, requerendo ou manifestando extroversão. $O$ jogo pode classificar-se desde os simples movimentos até um complexosistema de regras. É possivel jogar usando apenas os movimentos do corpo, como também utilizando as combinações de um sistema de regras para o uso do computador.

A criança explora seus sentimentos $\mathrm{e}$ emoções através do jogo, da mesma forma como explora o mundo exterior através de percepções.

É na escola que, infelizmente, a criança se afasta do jogo. Embora reconhecendo a importância do jogo nas relaçōes infantis, a escola não o privilegia, preenchendo seu espaço por tarefas escolares através de mecanismos de repetição. Em decorrência disso, as horas de estudo ocupam muito tempo, sendo deixados de lado, muitas vezes, o jogo e todos os valores que lhe são intrínsecos. 
Naescola,odesenvolvimentointelectual da criança é o principal objetivo, sendo deixadas de lado, muitas vezes, atividades lúdicas, porserem consideradasnum segundo plano. Além disso, não são propostas atividades que substituam o ludismo $e$ as formas lúdicas de exploração do mundo perdem-se, dando lugar a sistematizaçóes de estudo. Portanto, diminuem-se as horas de jogo, substituindo-as por atividades escolares repetitivas.

Consequentemente, a fantasia, a forma fantasiosa de recriar a realidade cede lugar ao treinamento precoce de habilidades intelectuais, ou mesmo aos mecanismos de repetiçăo de soluções encontradas pelo mundo adulto.

A escola preocupa-se, nas primeiras séries do primeiro grau, com a alfabetização, ou seja, com a aquisiçāo do código escrito, introduzindo a criança no universo da expressão escrita, queimando a etap̣a da oralidade.

O inicio das atividades de ler e escrever desconsidera as atividades primárias da língua que são ouvir eo falar, desenvolvido na familia e na pré-escola. Vemos aí um esquecimento da oralidade ou a oralidade como aspecto secundário, quando a mesma deveria ser o início do início das atividades da criança na escola.

Os objetivos básicos da oralidade são:

1) explorar sentimentos e emoçōes através do jogo lúdico;

2) valorizar a autonomia do som, sua independência do significado da palavra como uma etapa natural do desenvolvimento lingüistico;

3) privilegiar a sonoridade;

4) conduzir a criança ao prazer da espontaneidade poética;

5) explorar o mundo pela fantasia do jogo.

Desde sua mais remota infância, o ser humano é acompanhado pelo texto oral, através decantigas de ninar, jogos de palavras e de fonemas, das canções folclóricas e das cantigas de roda, provocandoo prazer estético e auxiliando na descoberta e no dominio do código oral. Por isso, é muito importante iniciar a atividade literária com as crianças, explorando a oralidade.

A poesia, na escola, deve oferecer a experiência de o sujeito tornar-se sujeito de sua língua .

\section{Reforências}

BRAGA, Maria Lúcia Santaella. Produgảo de linguagem \& isevlogia Sáo Paulo, Cortez Editora, 1960, 160 p.

CAPARELLLL, Sérgio Televisio, programas infantis e criancas'. In: ZILBERMAN, Regina (org) A produpio cuifunal pura a crianç. Porto Alegre, Mercado Aberto, 1984.

FERNANDES, Florestan. Foldore $e$ madança soctal na cidade de Sīo Paulo. Petrópolis, Vozes, 1979.

FREIRE, Paulo Educapẫo e mudança. Sào Paulo, Paz e Terra, $1979.179 \mathrm{p}$.

LOWENFELD, Viktor. 0 descrobloimento da capacidade criakrn Sảo Paulo, Mestre Jou, 1977

PEIRCE, Ch. S. Semiótica. Süo Paulo, Perspectiva, 1971.

PENTEADO, Heloisa Dupas. Teleoisio e escola: conflito ou Coopenciçîio? São Paulo, Cortez, 1991, 175 p.

PERROTI, Edmir. 'A criança e a produçăo cultural'. In: ZIL BERMAN, Regina (org.) A produçaio cuitural para a crimgat Porto Alegre, Mercado Aberto, 1954.

PIAGET, Jean A linguagen e o pensamento da crianca. Rio de Janeiro, Editora Funda de Cultura, 1973, 337 p.

PIAGET, Jean. A fonmagio do simblo sa criaga. Rio de Janeiro, Paze Tern, 1929.

SAUSSURE, Ferdinand de. Carso de linguística genal. São Paulo, Cultrix, $\quad 1972,279 \mathrm{p}$.

SAVIANI, Demerval. Escoda e demacracia. Sio Paulo, Cortez, $1984,96 \mathrm{p}$.

ZILBERMAN, Regina e MAGALHẢES, Ligia Cadermátori. Liknahura infontl: adtuitarissos e mancipacian. Sio Paulo, Ática, 1982, 160 p. 